A

$€$

\title{
DOKONYWANIE CZYNNOŚCI PROCESOWYCH PRZED SĄDEM KOŚCIELNYM JAKO OKOLICZNOŚĆ WYŁĄCZAJĄCA ODPOWIEDZIALNOŚĆ ZA NARUSZENIE DÓBR OSOBISTYCH. GLOSA DO WYROKU SĄDU APELACYJNEGO W BIAŁYMSTOKU Z DNIA 12 STYCZNIA 2017 R., I ACA 676/16
}

Streszczenie

Glosa omawia wyrok Sądu Apelacyjnego w Białymstoku, w którym sąd ten uznał działanie w ramach czynności stron procesu przed sądem kościelnym za okoliczność wyłączającą odpowiedzialność za naruszenie dóbr osobistych osoby fizycznej. Według autorki glosy na aprobatę zasługuje zarówno stanowisko co do dopuszczalności drogi sądowej przed sądami państwowymi w sprawach o ochronę dóbr osobistych naruszonych przed sądem kościelnym, jak też pogląd, iż ochrona dóbr osobistych nie przysługuje w przypadku zaistnienia okoliczności wyłączających bezprawność naruszenia takiego dobra. Działanie przed sądem kościelnym, którego funkcjonowanie aprobowane jest $\mathrm{w}$ ustawodawstwie państwowym, mieści się w grupie przypadków działania w ramach porządku prawnego. Kwalifikacja działania w ramach przysługujących stronie praw procesowych, zarówno w przypadku działań przed sądem państwowym, jak i sądem kościelnym, wymaga stwierdzenia, że działania te są oparte na istniejącym prawie podmiotu do działania, działaniu w granicach kompetencji zakreślonych przez porządek prawny, przytaczaniu okoliczności prawdziwych (lub co do których istnieją uzasadnione podstawy do uznawania ich za prawdziwe) w sposób oględny i w zakresie niezbędnym dla realizacji własnego prawa.

Słowa kluczowe: dobra osobiste; prawo kanoniczne; prawo państwowe; sąd kościelny

$* * * * *$

* Dr hab., prof. KUL, Katedra Postępowania Cywilnego, Wydział Prawa, Prawa Kanonicznego i Administracji, Katolicki Uniwersytet Lubelski Jana Pawła II, Al. Racławickie 14, 20-950 Lublin, e-mail: joannamisztal@kul.pl. ORCID 0000-0001-8849-5447. 


\section{WPROWADZENIE}

Wyrokiem z dnia 12 stycznia 2017 r. ${ }^{1}$ Sąd Apelacyjny w Białymstoku zmienił częściowo wyrok Sądu Okręgowego w Suwałkach w ten sposób, że zobowiązał pozwanego do złożenia powódce oświadczenia w formie pisemnej listu poleconego ze zwrotnym potwierdzeniem odbioru wysłanego do powódki w terminie dwóch tygodni od uprawomocnienia się wyroku o następującej treści: „Ja C. K. odwołuję, jako niezgodne z prawdą, twierdzenia odnośnie tego, że w rodzinie I. K. dochodziło do związków kazirodczych, a sama I. K. pozostawała w ośmioletnim związku pozamałżeńskim, prócz syna $\mathrm{M}$. K. urodziła dziecko, które przy jej udziale zaginęło w niewyjaśnionych okolicznościach. Przepraszam I. K. za opisane wyżej twierdzenia." Nadto Sąd Apelacyjny obniżył kwotę zasądzonego zadośćuczynienia z 10000 zł do 3000 zł oraz oddalił dalej idącą apelację pozwanego.

Wskazany wyrok wydany w sprawie o ochronę dóbr osobistych może być analizowany na kilku płaszczyznach: katalogu dóbr osobistych, środków ochrony dóbr osobistych, zasad określenia odpowiedniej sumy tytułem zadośćuczynienia pieniężnego etc. Na podkreślenie zasługuje rzetelna analiza tak samego pojęcia dóbr osobistych, jak i dobra osobistego w postaci czci człowieka. Słusznie wskazano, że cześć człowieka posiada dwa przejawy: cześć zewnętrzną (dobre imię) oraz cześć wewnętrzną (godność osobistą). Cześć zewnętrzna to opinia, którą o danej osobie mają inni, a cześć wewnętrzna, to poczucie osoby o swojej wartości, oczekiwanie przez nią szacunku od innych. Odpowiednio do tego rozróżnienia różnicuje się naruszenia czci. Wyodrębnia się zniesławienie - naruszenie czci zewnętrznej, dobrego imienia, oraz znieważenie - naruszenie czci wewnętrznej, godności osobistej.

Jednak niesygnalizowanym wyżej zagadnieniom chciałabym poświęcić niniejszą glosę, choćby dlatego, że o ile orzeczeń w sprawach o ochronę dóbr osobistych zapada wiele, o tyle niewiele z nich dotyczy naruszenia dóbr osobistych w toku postępowania przed sądem. Tymczasem glosowane orzeczenie nie dość, że dotyka problemu wykonywania praw proceso-

1 Wyrok Sądu Apelacyjnego w Białymstoku z dnia 12 stycznia 2017 r., I ACa 676/16, LEX nr 2229137, LEGALIS nr 1576465. 
wych, to jeszcze dotyczy tak szczególnej sytuacji, jak ocena przez sąd państwowy tego rodzaju czynności dokonywanych przed sądem kościelnym.

\section{PRZEDSTAWIENIE OKOLICZNOŚCI SPRAWY}

Warto skrótowo przytoczyć najważniejsze fakty z analizowanej sprawy. Postępowanie, w którym zapadł wyrok Sądu Apelacyjnego w Białymstoku z dnia 12 stycznia 2017 r., zainicjowane zostało pozwem I. K. skierowanym przeciwko jej byłemu mężowi C. K. o:

- zobowiązanie pozwanego do złożenia powódce przed Sądem oświadczenia ustnego o treści: „Ja, C. K. odwołuję jako sprzeczne z rzeczywistością twierdzenia podane w pozwie wniesionym do Sądu B. Diecezji (...) o orzeczenie nieważności małżeństwa C. K. z I. K. oraz moje zeznania złożone w przedmiotowej sprawie, w których oświadczyłem, że I. K. jest chora psychicznie, w jej rodzinie były związki kazirodcze, mające skutkować chorobami psychicznymi, że I. K. miała ośmioletni związek z szefem z pracy, leczyła się psychiatrycznie, że urodziła dziecko i sprzedała je na narządy. Równocześnie przepraszam I. K. i jej rodzinę za złożenie takich pisemnych oświadczeń i zeznań sprzecznych z rzeczywistością",

- zasądzenie na jej rzecz 20000 zł tytułem zadośćuczynienia za naruszenie dóbr osobistych, płatnych w terminie 14 dni od uprawomocnienia się orzeczenia wraz z ustawowymi odsetkami od dnia wniesienia pozwu do dnia zapłaty.

Sądy państwowe obu instancji ustaliły, że powódka I. K. była żoną C. K. Związek małżeński stron został rozwiązany prawomocnym wyrokiem Sądu Wojewódzkiego w Suwałkach z dnia 30 marca 1995 r. Pomimo rozwiązania małżeństwa strony pozostawały w otwartym konflikcie: w $1998 \mathrm{r}$. pozwany wystąpił z wnioskiem o zaprzeczenie ojcostwa, a powództwo zostało oddalone; z kolei postanowieniem z dnia 8 lipca 2010 r. Sąd Rejonowy w Suwałkach pozbawił C. K. władzy rodzicielskiej nad synem.

W dniu 28 stycznia 2011 r. pozwany wystąpił do sądu kościelnego właściwej diecezji z żądaniem stwierdzenia nieważności sakramentu małżeństwa łączącego strony. Proces kanoniczny toczył się zgodnie z regułami tajności. W toku procesu pozwany podnosił, że powódka leczyła się 
psychiatrycznie, pozostawała w czasie trwania małżeństwa w związku pozamałżeńskim, a sam związek z pozwanym zawarła, zamierzając się już związać z innym mężczyzną. Utrzymywał ponadto, że powódka urodziła dziecko, które zaginęło bez wieści, a członkowie jej bliskiej rodziny zawierali między sobą związki małżeńskie. Pozwany w toku postępowania twierdził także, że powódka była chora psychicznie. Analogiczne informacje o powódce były przekazywane w rodzinie pozwanego.

W odpowiedzi na powiadomienie o przyjęciu skargi przed sądem kościelnym do rozpoznania powódka złożyła oświadczenie, w którym wskazała, iż nie wyraża gotowości pogodzenia się z C. K. Przeczyła wypowiadanym pod jej adresem twierdzeniom i odmawiała uczestnictwa w procesie kanonicznym. Wskazywała ponadto, że - zaznajamiając się z pismami w procesie kanonicznym - głęboko przeżywała zarzuty stawiane pod jej adresem i rozmawiała na ten temat z członkami swojej rodziny.

Wyrokiem z dnia 29 grudnia 2014 r. sąd kościelny pierwszej instancji potwierdził ważność małżeństwa stron. W uzasadnieniu wyroku wskazano, że C. K., działający w tamtym procesie jako powód, zaskarżał ważność małżeństwa, wysuwając argument rzekomej choroby psychicznej I. K. i bazując na domniemaniach, plotkach oraz pomówieniach, takich jak związki kazirodcze panujące w rodzinie pozwanej, które miały skutkować jej chorobami psychicznymi, jej rzekomy ośmioletni związek z szefem z pracy, rzekome leczenie się psychiatryczne i stałe przyjmowanie leków, urodzenie przez nią dziecka i sprzedanie na narządy.

W tak ustalonym stanie faktycznym sądy państwowe obu instancji uznały za bezzasadny zarzut niedopuszczalności drogi sądowej, podnosząc, że wykluczone jest przyjęcie, iż w procesie kanonicznym nie obowiązuje ochrona dóbr osobistych. Stąd też, gdy informacje dotyczące dóbr osobistych, a podawane w procesie kanonicznym, nie będą obiektywnie uzasadnione usprawiedliwionymi celami procesu kanonicznego, osoba fizyczna może dochodzić ochrony swoich dóbr osobistych przed sądem w sprawie cywilnej, w szczególności dobra osobistego w postaci swojej godności (poczucia własnej wartości), jak również dobra osobistego w postaci dobrego imienia (czci zewnętrznej) ${ }^{2}$. Oceniły, że podniesienie nie-

2 Na temat pojęcia czci człowieka zob. np. Wierciński 2002, 57-72; Pazdan, w: Safjan (red.) 2012, 1238-1241. 
prawdziwych zarzutów co do karygodnych zachowań powódki w procesie kanonicznym spowodowało ich większy zasięg, a w konsekwencji znaczną krzywdę moralną.

\section{SPRAWA CYWILNA}

Zadanie glosatora, który aprobuje rozstrzygnięcie sądowe, jest bardzo trudne, ponieważ każdorazowo ociera się on o niebezpieczeństwo powielenia argumentacji przytoczonej przez sąd. Pomimo dostrzeżenia tego niebezpieczeństwa warto omówić wyrok Sądu Apelacyjnego w Białymstoku z dnia 12 stycznia 2017 r., ponieważ dotyka on - poza wspominanymi uprzednio - kilku zagadnień, z których niektóre mają charakter fundamentalny, a inne - rzadko spotykany w praktyce. Nie dążąc do przygotowania wyczerpującego komentarza do wszystkich istotnych zagadnień prawnych pojawiających się w przedstawionym wyroku i jego uzasadnieniu, należy skoncentrować rozważania na dwóch polach: dopuszczalności drogi sądowej w sprawach o ochronę dóbr osobistych naruszonych przez uczestnika procesu kanonicznego oraz - w przypadku przesądzenia dopuszczalności drogi sądowej - niektórych przesłankach wyłączających możliwość uwzględnienia powództwa o ochronę dóbr osobistych.

Zgodnie $\mathrm{z}$ art. 1 Kodeks postępowania cywilnego ${ }^{3}$ normuje postępowanie sądowe w sprawach ze stosunków z zakresu prawa cywilnego, rodzinnego i opiekuńczego oraz prawa pracy, jak również w sprawach z zakresu ubezpieczeń społecznych oraz $\mathrm{w}$ innych sprawach, do których przepisy tego Kodeksu stosuje się z mocy ustaw szczególnych. Sprawy te są sprawami cywilnymi, do rozpoznania których powołane są sądy powszechne oraz Sąd Najwyższy, chyba że przepisy szczególne przekazują je do właściwości sądów szczególnych lub innych organów (art. 2 § 1 i 3 k.p.c.). Równocześnie stosownie do art. $199 \S 1$ pkt 1 k.p.c. sąd cywilny odrzuca pozew, gdy droga sądowa jest niedopuszczalna.

Cytowane regulacje nie pozostawiają cienia wątpliwości, że fundamentalne znaczenie dla oceny możliwość merytorycznego rozpoznania

3 Ustawa z dnia 17 listopada 1964 r. - Kodeks postępowania cywilnego, tekst jedn. Dz. U. z 2019 r. poz. 1460 z późn. zm. 
sprawy przez sąd cywilny (scil. państwowy) ma przesądzenie dopuszczalności drogi sądowej. W realiach sprawy, w której zapadło glosowane orzeczenie, zarzut niedopuszczalności drogi sądowej został wprost wypowiedziany, a sądy obu instancji uznały go za nieuzasadniony. Sąd Okręgowy podkreślił, że niedopuszczalne jest przyjęcie, że w procesie kanonicznym nie obowiązuje ochrona dóbr osobistych. Natomiast Sąd Apelacyjny odwołał się szerzej do zagadnień przedmiotu sprawy, czyli do przedstawionego pod osąd roszczenia i przytoczonego przez powódkę stanu faktycznego, akcentując, że zasadność dochodzonego roszczenia pozostaje bez znaczenia dla możliwości rozpoznania sprawy przez sąd.

Przedstawione stanowisko sądów państwowych zasługuje na pełne podzielenie, choć wydaje się, że warto zwrócić uwagę na dodatkową argumentację, częściowo odniesioną do stosunku państwo - Kościół Katolicki, a dokładniej sądy państwowe - sądy kościelne. Przedmiotem sprawy było bowiem żądanie udzielenia ochrony dóbr osobistych, które wedle twierdzeń powódki zostały naruszone poprzez czynności procesowe pozwanego dokonywane w procesie kanonicznym.

Przypomnieć przychodzi, że wedle dominującego w doktrynie ${ }^{4}$ i orzecznictwie ${ }^{5}$ stanowiska dopuszczalność drogi sądowej nie jest zależna od merytorycznej przesłanki, która warunkuje uwzględnienie powództwa.

4 Zamiast wielu zob. Pietrzkowski 1999, 9-12 wraz z powołaną tam literaturą; Pilich 2010, 342-349; Gudowski 2010, 410-428; Zedler 2011, 557. Por. jednak uwagi krytyczne Błaszczaka 2015, 25-31.

5 Zamiast wielu: uchwała Sądu Najwyższego z dnia 8 stycznia 1992 r., III CZP 138/91, OSNC 1992/7-8/128; postanowienie Sądu Najwyższego z dnia 22 kwietnia 1998 r., I CKN 1000/97, OSNC 1999/1/6; postanowienie Sądu Najwyższego z dnia 10 marca 1999 r., II CKN 340/98, OSNC 1999/9/161; wyrok Trybunału Konstytucyjnego z dnia 10 lipca 2000 r., SK 12/99, OTK 2000/5/143; postanowienie Sądu Najwyższego z dnia 22 sierpnia 2000 r., IV CKN 1188/00, OSNC 2001/1/20; uchwała Sądu Najwyższego z dnia 12 marca 2003 r., III CZP 85/02, OSNC 2003/10/129; postanowienie Sądu Najwyższego z dnia 6 maja 2003 r., V CK 435/02, LEX nr 303667; postanowienie Sądu Najwyższego z dnia 14 września 2004 r., III CK 566/03, LEX nr 176104; postanowienie Sądu Najwyższego z dnia 22 sierpnia 2007 r., III CZP 76/07, LEX nr 345575; postanowienie Sądu Najwyższego z dnia 4 grudnia 2009 r., III CSK 75/09, LEX nr 1431020; postanowienie Sądu Najwyższego z dnia 11 września 2014 r., III CZ 46/14, OSNC 2015/7-8/92. Odmiennie jednak uchwała Sądu Najwyższego z dnia 20 kwietnia 1970 r., III CZP 4/70, OSNC 1970/9/146; uchwała Sądu Najwyższego z dnia 20 września 1996 r., III CZP 72/96, OSNC 1997/1/4. 
Przedmiotem oceny na etapie badania dopuszczalności drogi sądowej jest określenie, czy twierdzenie powoda o istnieniu albo nieistnieniu określonej normy indywidualno-konkretnej przedstawione sądowi celem wiążącego ustalenia jego istnienia albo nieistnienia mieści się w kręgu określonym regulacjami art. 1 k.p.c. lub art. 45 ust. 1 Konstytucji RP ${ }^{67}$. Skoro tak, nie może budzić wątpliwości, że wniesiona przez powódkę sprawa miała charakter sprawy cywilnej w rozumieniu art. 1 k.p.c. w znaczeniu materialnym - miała wszak oparcie w przepisach Kodeksu cywilnego ${ }^{8}$, zwłaszcza zaś normach art. 23-24 k.c. i art. 448 k.c. oraz odnosiła się do stosunku prawnego między równorzędnymi podmiotami. Skierowanie tej sprawy do sądu państwowego miało prowadzić do wymierzenia sprawiedliwości, a więc do rozstrzygania o prawach danego podmiotu9. Równocześnie brak normy szczególnej, która wyłączałaby tego rodzaju sprawę z kognicji sądów cywilnych, zwłaszcza że gdyby sąd powszechny (cywilny) odrzucał pozew z powodu niedopuszczalności drogi sądowej, nie może poprzestać na stwierdzeniu, że sprawa przedstawiona do rozstrzygnięcia nie jest sprawą cywilną w rozumieniu art. 1 k.p.c., lecz zobowiązany jest także wskazać sąd, do właściwości którego rozpoznanie tej sprawy, na którymkolwiek jej etapie, zostało ustawowo zastrzeżone ${ }^{10}$. Konstatację tę potwierdza również brzmienie art. 77 ust. 2 Konstytucji RP, który zakazuje zamykania drogi sądowej dla dochodzenia naruszonych praw lub wolności.

Art. 25 ust. 3 Konstytucji RP przewiduje zasadę poszanowania autonomii oraz wzajemnej niezależności państwa i związków wyznaniowych - każdego w swoim zakresie, co oznacza zarówno autonomię (swobodę w sferze wewnętrznej, „we własnym zakresie”), jak i niezależność odnoszącą się do relacji zewnętrznych, a zwłaszcza braku wzajemnego podpo-

6 Konstytucja Rzeczypospolitej Polskiej z dnia 2 kwietnia 1997 r., Dz. U. z 1997 r. Nr 78 , poz. 483 z późn. zm.

7 Wyrok Trybunału Konstytucyjnego z dnia 10 lipca 2000 r., SK 12/99, OTK 2000/5/143.

8 Ustawa z dnia 23 kwietnia 1964 r. - Kodeks cywilny, tekst jedn. Dz. U. z 2019 r. poz. 1145 z późn. zm.

9 Wyrok Trybunału Konstytucyjnego z dnia 26 kwietnia 2005 r., SK 36/03, OTK-A 2005/4/40.

10 Postanowienie Sądu Najwyższego z dnia 21 maja 2002 r., III CK 53/02, OSNC $2003 / 2 / 31$. 
rządkowania państwa związkom wyznaniowym, ale także związków wyznaniowych państwu ${ }^{11}$. Sąd Apelacyjny słusznie uznał, że to, iż naruszenie dóbr osobistych miało nastąpić przed sądem kościelnym, stanowi jedynie element stanu faktycznego, a nie przesądza o braku możliwości rozpoznania sprawy przez sąd państwowy. Oczywiste jest bowiem, że rozstrzygnięcie sądowe dotyczące ochrony dóbr osobistych nie stanowiłoby ingerencji organów państwowych w sprawy wewnętrzne związku wyznaniowego ${ }^{12}$, w szczególności w wydawane przez organy związku wyznaniowego rozstrzygnięcia lub przebieg postępowania przed takimi organami. W procesie o ochronę dóbr osobistych przedmiotem oceny jest nie działanie organów związku wyznaniowego, ale działanie osoby fizycznej przed takim organem występującej.

3. NARUSZENIE DÓBR OSOBISTYCH PRZEZ POSĄDZENIE O PONIŻAJĄCE WŁAŚCIWOŚCI I DZIAŁANIA W RAMACH POSTĘPOWANIA SĄDOWEGO (PRZED SĄDEM PAŃSTWOWYM)

Po raz kolejny dla oczyszczenia przedpola rozważań należy jedynie krótko zasygnalizować, że cześć, dobre imię, dobra sława człowieka są pojęciami obejmującymi wszystkie dziedziny jego życia osobistego, zawodowego i społecznego. Naruszenie czci może więc nastąpić zarówno przez pomówienie o nieodpowiednie postępowanie w życiu osobistym i rodzinnym, jak i przez zarzucenie niewłaściwego postępowania w życiu zawodowym, naruszające dobre imię danej osoby i mogące narazić ją na utratę zaufania potrzebnego do wykonywania zawodu lub innej działal-

11 Szerzej zob. Góralski, Pieńczyk 2000, 11-23; Borecki 2012, 85-109; Zarzycki 2014, 69-117; Stanisz 2015, 159-185 wraz z powołaną tam literaturą.

12 W postanowieniu z dnia 12 maja 2016 r. (IV CSK 529/15, OSNC 2017/3/35) Sąd Najwyższy przesądził, iż w sprawie o stwierdzenie ważności uchwały kościoła lub związku wyznaniowego dotyczącej obsady funkcji w tym kościele lub związku droga sądowa jest niedopuszczalna. Wagę tego rozstrzygnięcia pokazuje oddźwięk, który znalazło ono w doktrynie; zob. Brzozowski 2017, 117-123; Misztal-Konecka 2017, 64-74; Borecki 2018, 88-100. 
ności ${ }^{13}$. Naruszenie czci człowieka może nastąpić w drodze wypowiedzi ustnych lub pisemnych, w różnych okolicznościach. Tradycyjnie wyróżnia się wypowiedzi opisowe (dotyczące faktów) i oceniające (wyrażające opinię), przy czym pierwsze z nich weryfikuje się z punktu widzenia prawdy i fałszu, drugie zaś - są tylko wtedy dozwolone, gdy mieszczą się w granicach rzeczowej i konstruktywnej krytyki ${ }^{14}$. W odniesieniu do wypowiedzi opisowych bliższe wymogi ich dopuszczalności zostaną przedstawione w dalszej części opracowania.

W myśl art. 24 k.c. ochrona przysługuje jedynie przed bezprawnym zagrożeniem lub naruszeniem dobra osobistego. Jeżeli zatem naruszenie dobra osobistego nie jest bezprawne, poszkodowany nie może skutecznie dochodzić jego ochrony ${ }^{15}$. Powszechnie przyjmuje się, że o bezprawności naruszenia dobra osobistego decyduje kryterium obiektywne, a mianowicie sprzeczność z normami prawnymi lub regułami postępowania wynikającymi z zasad współżycia społecznego ${ }^{16}$. Warto również odnotować, że $\mathrm{z}$ art. 24 k.c. wynika domniemanie bezprawności naruszenia, a zatem to pozwanego obciąża dowód prawdziwości postawionych zarzutów, on też ponosi konsekwencje ewentualnego niepowodzenia dowodowego ${ }^{17}$.

Tradycyjnie przyjmuje się, że bezprawność wyłącza zgoda poszkodowanego, działanie w ramach porządku prawnego ${ }^{18}$, działanie w wykona-

13 Wyrok Sądu Najwyższego z dnia 29 października 1971 r., II CR 455/71, OSNC 1972/4/77.

14 Szpunar 1979, 127-142; Wierciński 2002, 108-131. Zob. też Kordasiewicz 1985, 22-28; Święcka 2011, 53-66.

15 Wyrok Sądu Najwyższego z dnia 5 maja 1999 r., III CKN 248/98, LEX nr 1211726.

16 Zamiast wielu zob. Szpunar 1979, 156; Sadomski 2003, 42. W judykaturze zob. wyrok Sądu Najwyższego z dnia 25 października 1982 r., I CR 239/82, LEX nr 766611; wyrok Sądu Najwyższego z dnia 19 października 1999 r., I CKN 979/98, LEX nr 527153; wyrok Sądu Najwyższego z dnia 7 listopada 2002 r., II CKN 1293/00, OSNC 2004/2/27; wyrok Sądu Najwyższego z dnia 19 kwietnia 2012 r., IV CSK 406/11, OSNC-ZD 2012/3/68.

17 Sadomski 2003, 44.

18 Jako typowe przykłady M. Pazdan (w: Safjan (red.) 2012, 1273) podaje zwłaszcza sporządzenie ekspertyzy przez biegłego, złożenie zeznań przez świadka lub biegłego, postawienie zarzutów w akcie oskarżenia lub w piśmie procesowym, umieszczenie na świadectwie szkolnym niskiej oceny z zachowania, ocena niedostateczna na egzaminie, prowadzenie w zakładzie pracy postępowania wyjaśniającego, czy pracownik nie popełnił przestępstwa, zawiadomienie przez pracodawcę organów ścigania o przestępstwie popełnionym przez pra- 
niu prawa podmiotowego oraz nadużycie prawa podmiotowego, a także - choć w tym zakresie brak zgodności w doktrynie - działanie w obronie interesu zasługującego na ochronę ${ }^{19}$. W literaturze przedmiotu uchylenie bezprawności ze względu na wykonywanie prawa podmiotowego uznaje się niekiedy za podgrupę uchylenia bezprawności ze względu na działanie w ramach obowiązującego porządku prawnego, albowiem wykonywanie praw podmiotowych odbywa się właśnie $\mathrm{w}$ ramach zakreślonych przez porządek prawny ${ }^{20}$. W tejże podgrupie wymienia się zwłaszcza wykonywanie praw podmiotowych strony w procesie, wykonywanie praw cywilnych w zakresie stosunków rodzinnych oraz wykonywanie prawa do obrony swoich praw podmiotowych w inny sposób ${ }^{21}$. Typowymi przykładami działania $\mathrm{w}$ ramach porządku prawnego ${ }^{22}$ są zatem działania stron (i ich pełnomocników) w trakcie postępowania sądowego, w tym składanie pism procesowych, wniosków dowodowych, wniosków o wyłączenie sędziego i wyłączenie biegłego, podważanie wiarygodności świadków i opinii biegłych, jak też składanie zeznań, przygotowywanie opinii przez biegłego, przedstawianie dokumentów, powiadomienie o podejrzeniu popełnienia przestępstwa itd. ${ }^{23}$

cownika, działania podjęte w ramach funkcjonowania komisji rewizyjnej, jeżeli mieszczą się w granicach jej kompetencji, uchwała właściwego organu statutowego koła łowieckiego o skreśleniu z listy członków, jeśli nawet została przez organ nadrzędny zmieniona.

19 Szpunar 1979, 155-170; Sośniak 1985, 63-74; Bidziński, Serda 1986, 16-47; Dobosz 1986, 289-312; Cisek 1989, 71-113; Wierciński 2002, 154-165; Kosiór, Puchała 2017, 113-182.

20 Samo działanie w ramach porządku prawnego, w tym w szczególności wykonywanie prawa podmiotowego, nie zawsze oznacza działania w ramach określonych kompetencji. Wyłączeniem bezprawności objęte jest jedynie działanie w granicach zakreślonych porządkiem prawnym. Zob. np. wyrok Sądu Najwyższego z dnia 7 listopada 2000 r., I CKN 1149/98, LEX nr 50831.

21 Bidziński, Serda 1986, 43.

22 Niektóre z wymienionych sytuacji kwalifikować można bardziej szczegółowo jako wykonywanie praw podmiotowych strony w procesie.

23 Wyrok Sądu Najwyższego z dnia 3 maja 1968 r., II CR 163/68, LEX nr 6326; wyrok Sądu Najwyższego z dnia 28 października 1971 r., I CR 425/71, LEX nr 7007; wyrok Sądu Najwyższego z dnia 19 października 1989 r., II CR 419/89, OSP 1990/11-12/377; wyrok Sądu Apelacyjnego w Katowicach z dnia 28 czerwca 2000 r., I ACa 353/00, LEX nr 46684; wyrok Sądu Apelacyjnego w Poznaniu z dnia 8 marca 2008 r., I ACa 1084/6, LEX nr 44621; 
Jednakże podkreślić trzeba, że samo istnienie podstawy prawnej (sformułowanej wprost lub wywiedzionej z całokształtu regulacji) dla określonego działania nie oznacza, że w każdym przypadku działanie to nie może być zakwalifikowane jako bezprawne. W szczególności w ramach realizacji praw procesowych możliwe jest podnoszenie informacji ze sfery prywatnej, a działanie takie nie będzie bezprawne, jeśli podane informacje są prawdziwe i istotne dla rozstrzygnięcia sprawy. Natomiast podnoszenie zniesławiających twierdzeń, choćby prawdziwych, nieistotnych dla wyniku sprawy, jest bezprawnym naruszeniem dóbr osobistych. Tytułem przykładu warto przywołać wyrok Sądu Najwyższego z dnia 3 maja 1968 r., w którym stwierdzono, że nie stanowią bezprawnego działania w rozumieniu art. $24 \S 1$ k.c. oświadczenia składane w sprawach karnych i cywilnych na uzasadnienie roszczenia skargi, względnie na uzasadnienie obrony, jeżeli wynikają one z uprawnień działającego, a więc gdy przedmiotowo zdolne są służyć obronie prawa osoby działającej i gdy podmiotowo podyktowane są wolą działającego - wystąpienia w obronie swego prawa ${ }^{24}$. Całkowicie odmiennie przedstawia się natomiast sytuacja w przypadku celowego i świadomego złożenia fałszywego zawiadomienia o przestępstwie $^{25}$ lub skierowanego na dyskredytację dłużnika złożenia wniosku o wszczęcie postępowania egzekucyjnego ${ }^{26}$.

Podejmując próbę zebrania elementów określających granice wykonywania praw procesowych, należy rozpocząć od tego, że rozszerzone granice działania $\mathrm{w}$ razie dochodzenia swoich praw nie pozwalają na przedstawianie nieprawdy. Stąd też uczestnik postępowania nie może po-

wyrok Sądu Apelacyjnego w Katowicach z dnia 17 stycznia 2017 r., I ACa 772/16, LEX nr 2231153.

24 Wyrok Sądu Najwyższego z dnia 3 maja 1968 r., II CR 163/68, LEX nr 6326. Podobnie wyrok Sądu Apelacyjnego w Warszawie z dnia 4 grudnia 1998 r., I ACa 1004/98, LEX nr 38033; wyrok Sądu Apelacyjnego w Poznaniu z dnia 18 kwietnia 2003 r., I ACa 265/13, LEX nr 1314843; wyrok Sądu Apelacyjnego w Katowicach z dnia 10 kwietnia 2015 r., I ACa 1106/14, LEX nr 1740665.

25 Wyrok Sądu Najwyższego z dnia 13 kwietnia 2000 r., III CKN 777/98, LEX nr 51361; wyrok Sądu Apelacyjnego w Gdańsku z dnia 11 stycznia 2001 r., I ACa 505/00, LEX nr 50094.

26 Wyrok Sądu Apelacyjnego w Krakowie z dnia 9 lutego 2000 r., I ACa 77/00, LEX nr 243205 . 
wołać się na dane charakteryzujące niekorzystnie sylwetkę przeciwnika, jeżeli ich nieprawdziwość jest mu znana. Należy natomiast dopuścić powołanie się na nie w pełni sprawdzone dane, potrzebne do obrony jego stanowiska w sprawie ${ }^{27}$.

W orzecznictwie zwrócono także uwagę, że nie zasługuje na ochronę działanie w wykonywaniu uprawnień procesowych, jeżeli przekracza rzeczowe potrzeby w ramach podjętej obrony lub dochodzenia praw. Przy ocenie rzeczowości obrony interesów analizuje się określoną wypowiedź w kontekście charakteru sprawy, który w znacznym stopniu determinuje celowość i potrzebę danej wypowiedzi, jak też w okolicznościach sprawy, które określone są treścią żądania i wymagającymi odparcia argumentami przeciwnika $^{28}$. Stąd też słusznie Sąd Apelacyjny w Lublinie uznał, że stanowi naruszenie dóbr osobistych użycie w piśmie procesowym sformułowań, które nie są oględne, przypisują wprost przeciwnikowi procesowemu naganne cechy, nie dotyczą przedmiotu postępowania, nie ograniczają się do wskazania faktów dotyczących przedmiotu postępowania podważających twierdzenia przeciwnika, lecz powołują także fakty odnoszące się do osoby przeciwnika negatywnie go charakteryzujące ${ }^{29}$.

Istotne znaczenie ma nadto sposób działania podmiotu, który stoi pod zarzutem naruszenia dóbr osobistych. W toku każdego procesu istnieje obowiązek poszanowania godności osoby, również oponenta procesowego, i zakaz używania sformułowań wykraczających poza potrzebę, czy zawierających bezpodstawne zarzuty. Stąd też forma, w której przedstawiane

27 Wyrok Sądu Najwyższego z dnia 19 lipca 1978 r., I CR 254/78, OSNCP 1979/6/121. Podobnie wyrok Sądu Najwyższego z dnia 19 października 1989 r., II CR 419/89, OSP 1990/11-12/377; wyrok Sądu Najwyższego z dnia 24 sierpnia 2011 r., IV CSK 587/10, LEX nr 1129156; wyrok Sądu Apelacyjnego w Białymstoku z dnia 26 sierpnia 2016 r., I ACa 260/16, LEX nr 2115456. Tak też np. Pazdan, w: Safjan (red.) 2012, 1279.

28 Wyrok Sądu Najwyższego z dnia 20 kwietnia 2006 r., IV CSK 2/06, OSNC 2007/2/30; wyrok Sądu Najwyższego z dnia 24 sierpnia 2011 r., IV CSK 587/10, LEX nr 1129156; wyrok Sądu Apelacyjnego w Krakowie z dnia 11 października 2013 r., I ACa 898/13, LEX nr 1480438; wyrok Sądu Apelacyjnego w Krakowie z dnia 23 kwietnia 2015 r., I ACa 186/15, LEX nr 1733703.

29 Wyrok Sądu Apelacyjnego w Lublinie z dnia 10 lipca 1998 r., I ACa 202/98, OSA 2000/2/6. Podobnie wyrok Sądu Najwyższego z dnia 25 kwietnia 1990 r., I CR 147/90, LEX nr 9026 . 
są zarzuty, powinna być oględna; w żadnym wypadku nie może dyskryminować czy szykanować ${ }^{30}$.

\section{DZIALANIE W CELU DOCHODZENIA PRAW W PROCESIE KANONICZNYM JAKO OKOLICZNOŚĆ WYŁĄCZAJĄCA BEZPRAWNOŚĆ}

Komentowany wyrok dotyczy działań podejmowanych przez pozwanego przed sądem kościelnym w celu dochodzenia swoich praw: powódka, występując z żądaniem ochrony dóbr osobistych, twierdziła, że jej dobra zostały naruszone $\mathrm{w}$ postępowaniu przed sądem biskupim, w toku którego w pismach i zeznaniach pozwanego wskazane zostały przyczyny nieważności sakramentu małżeństwa, które w ocenie powódki upokarzały ją ${ }^{31}$.

Kluczowym czynnikiem różnicującym w stosunku do judykatów zaprezentowanych powyżej jest to, że do naruszenia dóbr osobistych powódki miało dojść w toku postępowania w procesie przed sądem kościelnym. Skoro działanie w ramach porządku prawnego, jako okoliczność wyłączająca bezprawność naruszenia dobra osobistego, wymaga stwierdzenia, że obowiązuje norma prawna upoważniająca do naruszenia dobra osobistego, należy postawić pytanie, czy również działania podejmowane w procesie kanonicznym mogą korzystać z ochrony, którą orzecznictwo od dawna przyznaje działaniom przed sądem państwowym, czy również te działania należy kwalifikować jako podejmowane w ramach obowiązującego porządku prawnego. Udzielenie odpowiedzi na to pytanie ma istotne znaczenie z prawnego i społecznego punktu widzenia również z tego powodu, że obie społeczności, religijna i państwowa, tworzone są często przez tych samych ludzi.

Niewątpliwie prawo kanoniczne i sądownictwo kościelne w polskim porządku prawnym nie są tożsame z prawem państwowym i sądownictwem

30 Wyrok Sądu Najwyższego z dnia 19 lipca 1978 r., I CR 254/78, OSNCP 1979/6/121; wyrok Sądu Najwyższego z dnia 25 kwietnia 1990 r., I CR 147/90, LEX nr 9026. Tak też np. Pazdan, w: Safjan (red.) 2012, 1279.

31 Pozwany zarzucał powódce w toku procesu o stwierdzenie nieważności małżeństwa, że leczyła się psychiatrycznie, pozostawała w trakcie trwania małżeństwa w związku pozamałżeńskim, a sam związek z pozwanym zawarła, zamierzając się związać z innym mężczyzną, urodziła dziecko, które zaginęło bez wieści, oraz że w rodzinie powódki zawierano związki kazirodcze. 
państwowym. Prawo kanoniczne jednakże często do prawa państwowego odsyła w różnych kontekstach, czy to postulując jego znajomość, czy też zalecając przestrzeganie, uznając skuteczność lub obowiązywanie na forum kanonicznym ${ }^{32}$. Z drugiej strony, prawo kanoniczne nie stanowi części prawa państwowego, nie zostało bowiem wskazane jako źródło prawa $\mathrm{w}$ Konstytucji ${ }^{33}$; niewątpliwie nie obowiązuje zatem automatycznie $\mathrm{w}$ polskim porządku prawnym ${ }^{34}$. Widoczne jest jednak uwzględnianie norm prawa kanonicznego na gruncie prawa państwowego, np. co do osobowości prawnej kościelnych jednostek organizacyjnych, co do określenia reprezentacji kościelnych osób prawnych ${ }^{35}$, co do uznania statusu osoby duchownej etc. ${ }^{36}$, stąd teza o tym, że ustrojodawca polski optuje za zasadą wzajemnej niezależności i nieskuteczności prawa państwowego oraz prawa kościelnego ${ }^{37}$ jest zbyt daleko idąca. W praktyce bez wątpienia w pewnym zakresie prawo państwowe oddziałuje na prawo kanoniczne, zaś prawo kanoniczne - na prawo państwowe ${ }^{38}$.

Z przepisów konstytucyjnych, konkordatowych i ustawowych ${ }^{39}$ wywieść można istnienie zasady poszanowania autonomii i niezależności

32 Szerzej zob. Sobański 1999, 10-11.

33 Stanisz 2015, 171, 175.

34 Walencik 2013, 16.

35 Wyrok Sądu Najwyższego z dnia 7 lipca 2000 r., IV CSK 88/00, LEX nr 52448; wyrok Sądu Najwyższego z dnia 24 marca 2004 r., IV CK 108/03, OSNC 2005/4/65; wyrok Sądu Najwyższego z dnia 17 lutego 2005 r., IV CK 582/04, LEX nr 176007; uchwała Sądu Najwyższego z dnia 19 grudnia 2008 r., III CZP 122/08, OSNC 2009/7-8/115. Problematyka ta jest niezwykle szeroko dyskutowana w literaturze prawa wyznaniowego, zaś cele glosy nie wymagają przeprowadzenia jej szerszej analizy. Szerzej zob. Rzepecki 2013, 168-176 wraz z powołaną literaturą; Walencik 2013, 11-12 wraz z powołaną tam literaturą; Zarzycki 2014, 92-95; Stanisz 2015, 176-177.

36 Szerzej zob. Walencik 2013, 17-18; Rynkowski 2013, 39-50; Tunia 2015, 155-336.

37 Borecki 2012, 89.

38 Sobański 2002, 426-427; Uruszczak 2007, 7-13; Rzepecki 2013, 163-164.

39 Na mocy art. 5 Konkordatu między Stolicą Apostolską i Rzecząpospolitą Polską, podpisanego w Warszawie dnia 28 lipca 1993 r. (Dz. U. z 1998 r. Nr 51, poz. 318), przestrzegając prawa do wolności religijnej, Państwo zapewnia Kościołowi Katolickiemu, bez względu na obrządek, swobodne i publiczne pełnienie jego misji, łącznie z wykonywaniem jurysdykcji oraz zarządzaniem i administrowaniem jego sprawami na podstawie prawa kanonicznego.

Zgodnie z art. 2 ustawy z dnia 17 maja 1989 r. o stosunku Państwa do Kościoła Katolickiego w Rzeczypospolitej Polskiej (tekst jedn. Dz. U. z 2019 r. poz. 1347) Kościół 
Kościoła Katolickiego ${ }^{40}$ i państwa, każdego w swojej dziedzinie, z nich zaś istnienie gwarancji swobodnego rządzenia się przez Kościół Katolicki własnym prawem i wykonywania jurysdykcji ${ }^{41}$. Oznacza ona szerzej autonomię sądownictwa wyznaniowego i autonomię sądownictwa państwowego $^{42}$. Co oczywiste, przedmiotem władzy sądowniczej sprawowanej w Kościele są rzeczy duchowe (res spirituales) i rzeczy związane z duchowymi (res spirituales adnexae) ${ }^{43}$. W toku procesu kanonicznego podejmowane są rozmaite czynności procesowe i wykorzystywane są różne sposoby dowodzenia: oświadczenia stron, przyznanie sądowe, dokumenty publiczne i prywatne, zeznania świadków, orzeczenia biegłych, wizja lokalna i oględziny sądowe ${ }^{44}$. Mimo znacznego podobieństwa funkcji i sposobu funkcjonowania do sądów państwowych sądy kościelne nie mieszczą się w kręgu sądów, o których mówi Konstytucja RP, zaś działalność sądów kościelnych nie jest regulowana ustawą państwową. Nie usprawiedliwia to jednak podważania sądowego charakteru ich działalności, wyznaczonego zakresem zadań i funkcji. Sądy kościelne nie działają bowiem na terenie Rzeczypospolitej Polskiej nielegalnie, poza wiedzą i zgodą państwa ${ }^{45}$. Przeciwnie, Kościół Katolicki, jak już wskazano, może wykonywać swoją jurysdykcję w oparciu o przepisy Konkordatu, zwłaszcza art. 5, zaś w odniesieniu do spraw małżeńskich ${ }^{46}$ art. 10 ust. 3-4 Konkordatu wprost określa, że orzekanie o ważności małżeństwa kanonicznego, a także w innych

rządzi się w swych sprawach własnym prawem, swobodnie wykonuje władzę duchowną i jurysdykcyjną oraz zarządza swoimi sprawami.

40 Dalsze rozważania zostaną co do zasady ograniczone do analizy statusu sądów Kościoła Katolickiego, ponieważ właśnie przed takim sądem toczył się proces, w którym miało dojść do naruszenia dóbr osobistych powódki.

41 Zarzycki 2014, 86-87.

42 Rapacz 2007, 56; Stanisz 2015, 180-182; Bzdyrak 2017, 28-29.

43 Zgodnie z kan. 1401 Kodeksu Prawa Kanonicznego moca własnego i wyłacznego prawa Kościól rozpoznaje: sprawy dotyczące rzeczy duchowych i związanych z duchowymi; przekroczenie ustaw kościelnych oraz wszystkie inne, w których wchodzi w grę grzech, w tym to, co dotyczy ustalenia winy i wymierzenia kar kościelnych. Szerzej zob. np. Rapacz 2007, 60-63; Bar 2009, 224; Bzdyrak 2017, 23-24.

44 Bar 2009, 224-227.

45 Świto 2012, 156-157.

46 Co istotne, właśnie w toku sprawy o stwierdzenie nieważności małżeństwa miało dojść do naruszenia dóbr osobistych powódki. 
sprawach małżeńskich przewidzianych w prawie kanonicznym, należy do wyłącznej kompetencji władzy kościelnej, natomiast orzekanie w sprawach małżeńskich w zakresie skutków określonych w prawie polskim należy do wyłącznej kompetencji sądów państwowych ${ }^{47}$. Warto odnotować, że art. 10 ust. 5 Konkordatu przewiduje możliwość powiadamiania organów państwa i Kościoła o orzeczeniach zapadających przed ich sądami w sprawach małżeńskich, co potwierdza wniosek, iż niezależność i autonomia Kościoła Katolickiego i państwa nie oznaczają całkowitej izolacji ich struktur prawnych ${ }^{48}$.

Poczynione uwagi pozwalają ostatecznie zaakceptować stanowisko Sądu Apelacyjnego w Białymstoku co do tego, że również wykonywanie praw procesowych przed sądem kościelnym stanowi działanie w ramach obowiązującego porządku prawnego i korzysta z ochrony prawnej. Na ochronę taką nie zasługują jedynie działania, które wykraczają poza potrzebę procesową, stanowią podniesienie zarzutów subiektywnie nieprawdziwych lub zostały przeprowadzone w sposób, który sam w sobie stanowi naruszenie dóbr osobistych.

Dodać należy, że do odmiennych konstatacji nie prowadzi dostrzeżenie regulacji prawa kanonicznego, zgodnie z którymi proces kanoniczny najczęściej jest tajny wobec wszystkich innych, poza stronami postępowania $^{49}$. Ochrona prywatności stron w procesie kanonicznym nie wyłącza bowiem możliwości dojścia do naruszenia dóbr osobistych; proces kanoniczny zapewnia zawsze dostęp do niego stronom postępowania oraz osobom prowadzącym tenże proces.

Przedstawione uwagi, inspirowane wyrokiem Sądu Apelacyjnego w Białymstoku, odnoszą się wyłącznie do kwalifikacji czynności procesowych dokonywanych w procesach kanonicznych dotyczących ważności małżeństwa kanonicznego jako elementu polskiego porządku prawnego, a dokładniej działania zgodnie z prawem stanowiącego przesłankę uchylenia bezprawności naruszenia dobra osobistego. Szerzej ujęta rela-

47 Rapacz 2007, 56; Brzemia-Bonarek 2007, 45; Andrzejewska, Andrzejewski 2014-2015, 9-12.

48 Świto 2012, 152.

49 Greszata 2009, 403-406, 409-411. 
cja sądownictwa państwowego i kościelnego czeka natomiast niewątpliwie na swojego badacza.

\section{BIBLIOGRAFIA}

Andrzejewska, Marzena, Maciej Andrzejewski. 2014-2015. „Czy sąd kościelny jest innym sądem lub organem w rozumieniu art. 44 ustawy - Prawo o ustroju sądów powszechnych?" Roczniki Wydziału Nauk Prawnych i Ekonomicznych KUL. Prawo 10-11: 5-17.

Bar, Józef. 2009. „Współpraca sądów kościelnych z innymi podmiotami życia publicznego". W: Finis legis Christus. Ksiega pamiatkowa dedykowana Księdzu Profesorowi Wojciechowi Góralskiemu z okazji siedemdziesiątej rocznicy urodzin, red. Józef Wroceński, Jan Krajczyński, t. 1, 223-239. Warszawa: Wydawnictwo Uniwersytetu Kardynała Stefana Wyszyńskiego.

Bidziński, Zygmunt, Jerzy Serda. 1986. „Cywilnoprawna ochrona dóbr osobistych w praktyce sądowej". W: Dobra osobiste i ich ochrona w polskim prawie cywilnym. Zagadnienia wybrane, red. Józef S. Piątowski, 7-101. Wrocław: Zakład Narodowy im. Ossolińskich - Wydawnictwo Polskiej Akademii Nauk.

Błaszczak, Łukasz. 2015. „Problematyka sprawy cywilnej i drogi sądowej w kontekście zagadnienia sprawy konstytucyjnej i domniemania drogi sądu powszechnego z art. 177 Konstytucji”. W: Konstytucjonalizacja postępowania cywilnego, red. Łukasz Błaszczak, 3-54. Wrocław: Presscom.

Borecki, Paweł. 2012. „Autonomia kościołów i innych związków wyznaniowych we współczesnym prawie polskim". Studia z Prawa Wyznaniowego 15: 85-109.

Borecki, Paweł. 2018. „W sprawie autonomii i niezależności związku wyznaniowego - uwagi na tle postanowienia Sądu Najwyższego - Izba Cywilna z 12.5.2016 r., IV CSK 529/15". Polski Proces Cywilny 1: 88-100.

Brzemia-Bonarek, Aleksandra. 2007. „Pomoc sądowa pomiędzy sądami kościelnymi a państwowymi w celu uzyskania dokumentów niedostępnych dla strony w kanonicznym procesie małżeńskim (Analiza prawna zagadnienia i propozycje de lege ferenda)". W: Sędzia i Pasterz. Księga pamiątkowa w 50-lecie pracy ks. Remigiusza Sobańskiego w Sadzie Metropolitalnym w Katowicach (1957-2007), red. Honorata Typańska, 41-52. Katowice: Księgarnia św. Jacka. Brzozowski, Wojciech. 2017. „Niedopuszczalność sądowej kontroli prawidłowości stosowania przez związek wyznaniowy własnego prawa. Glosa do postanowienia Sądu Najwyższego z 12.5.2016 r., IV CSK 529/15”. Przegląd Sądowy 5: 117-123. 
Bzdyrak, Grzegorz. 2017. „Prawne gwarancje autonomii i niezależności Kościoła katolickiego w Polsce w zakresie władzy jurysdykcyjnej w sprawach małżeńskich". Przeglad Sejmowy 4: 19-38.

Cisek, Andrzej. 1989. Dobra osobiste i ich niemajątkowa ochrona w kodeksie cywilnym. Wrocław: Wydawnictwo Uniwersytetu Wrocławskiego.

Dobosz, Izabela. 1986. „Działanie w obronie uzasadnionego interesu jako okoliczność wyłączająca bezprawność naruszenia dóbr osobistych". W: Dobra osobiste $i$ ich ochrona $w$ polskim prawie cywilnym. Zagadnienia wybrane, red. Józef S. Piątowski, 289-312. Wrocław: Zakład Narodowy im. Ossolińskich - Wydawnictwo Polskiej Akademii Nauk.

Góralski, Wojciech, Andrzej Pieńczyk. 2000. Zasada niezależności i autonomii państwa i Kościoła w Konkordacie polskim z 1993 roku. Warszawa: Wydawnictwo Uniwersytetu Stefana Wyszyńskiego.

Greszata, Marta. 2009, „Zasada tajności i publiczności w sądownictwie kościelnym". W: Finis legis Christus. Księga pamiątkowa dedykowana Księdzu Profesorowi Wojciechowi Góralskiemu z okazji siedemdziesiątej rocznicy urodzin, red. Józef Wroceński, Jan Krajczyński, t. 1, 401-414. Warszawa: Wydawnictwo Uniwersytetu Kardynała Stefana Wyszyńskiego.

Gudowski, Jacek. 2010. „Wpływ Konstytucji i orzecznictwa Trybunału Konstytucyjnego na pojęcie dopuszczalności drogi sądowej”. W: Orzecznictwo Trybunału Konstytucyjnego a Kodeks postępowania cywilnego, red. Tadeusz Ereciński, Karol Weitz, 410-428. Warszawa: LexisNexis.

Kordasiewicz, Bogudar. 1985. „W sprawie obiektywnych i subiektywnych kryteriów oceny naruszania dóbr osobistych". W: Prace z prawa cywilnego wydane dla uczczenia pracy naukowej profesora Józefa Stanisława Piątowskiego, red. Bogudar Kordasiewicz, Ewa Łętowska, 17-28. Wrocław-Warszawa: Polska Akademia Nauk.

Kosiór, Mateusz, Agata Puchała. 2017. „Okoliczności wyłączające bezprawność naruszenia dóbr osobistych na gruncie Kodeksu cywilnego". W: Dobra osobiste, red. Izabela Lewandowska-Malec, wyd. 2, 113-182. Warszawa: C.H. Beck.

Misztal-Konecka, Joanna. 2017. „Glosa [do postanowienia Sądu Najwyższego z dnia 12 maja 2016 r., IV CSK 529/15]”. Orzecznictwo Sąów Polskich 6: 64-74.

Pietrzkowski, Henryk. 1999. „Prawo do sądu (wybrane zagadnienia)”. Przegląd Sadowy 11-12: 3-17.

Pilich, Mateusz. 2010. „Wpływ orzeczeń Trybunału Konstytucyjnego na Kodeks postępowania cywilnego". W: Orzecznictwo Trybunału Konstytucyjnego a Kodeks postępowania cywilnego, red. Tadeusz Ereciński, Karol Weitz, 319-409. Warszawa: LexisNexis. 
Rapacz, Józef. 2007. „Autonomia sądownictwa kościelnego”. Annales Canonici 3: 55-65.

Rynkowski, Michał. 2013. Sady wyznaniowe we wspótczesnym europejskim porządku prawnym. Wrocław: Prawnicza i Ekonomiczna Biblioteka Cyfrowa.

Rzepecki, Arnold. 2013. „Funkcjonowanie prawa kanonicznego w polskim porządku prawnym - zarys tematu". Acta Erasmiana 5: 163-184.

Sadomski, Jacek. 2003. „Naruszenie dóbr osobistych przez media”. Warszawa: Instytut Wymiaru Sprawiedliwości.

Safjan, Marek (red.). 2012. System prawa prywatnego, t. 1: Prawo cywilne-część ogólna, wyd. 2. Warszawa: C.H. Beck.

Sobański, Remigiusz. 1999. „Prawo kanoniczne a krajowy porządek prawny” Państwo i Prawo 6: 3-17.

Sobański, Remigiusz. 2002. „Czy prawo kościelne jest dziwne?” Śląskie Studia Historyczno-Teologiczne 2: 426-431.

Sośniak, Mieczysław. 1985. „Funkcje i skuteczność zgody osoby uprawnionej w zakresie ochrony dóbr osobistych". W: Prace z prawa cywilnego wydane dla uczczenia pracy naukowej profesora Józefa Stanisława Piatowskiego, red. Bogudar Kordasiewicz, Ewa Łętowska, 63-74. Wrocław-Warszawa: Polska Akademia Nauk.

Stanisz, Piotr. 2015. „Konstytucyjne zasady określające relacje państwa z kościołami i innymi związkami wyznaniowymi: autonomia i niezależność oraz współdziałanie". W: Katolickie zasady relacji państwo-kościót a prawo polskie, red. Józef Krukowski, Mirosław Sitarz, Henryk Stawniak, 159-185. Lublin: Towarzystwo Naukowe Katolickiego Uniwersytetu Lubelskiego Jana Pawła II. Szpunar, Adam. 1979. Ochrona dóbr osobistych. Warszawa: PWN.

Święcka, Krystyna. 2011. „Kryterium prawdziwości wypowiedzi a ochrona dóbr osobistych". Ruch Prawniczy, Ekonomiczny i Socjologiczny 4: 53-66.

Świto, Lucjan. 2012. „Rekwizycja cywilno-kanoniczna? Pomoc sądowa pomiędzy trybunałami kościelnymi a sądownictwem powszechnym w Polsce". Prawo Kanoniczne 2: 145-166.

Tunia, Anna. 2015. Recepcja prawa wewnętrznego związów wyznaniowych w prawie polskim. Lublin: Wydawnictwo KUL.

Uruszczak, Wacław. 2007. „Recepcja prawa kanonicznego w obowiązującym prawie polskim". Annales Canonici 3: 5-21.

Walencik, Dariusz. 2013. „Prawo kanoniczne (wewnętrzne) związków wyznaniowych a prawo polskie". Przeglad Sąowy 5: 11-25.

Wierciński, Jacek. 2002. Niemajątkowa ochrona czci. Warszawa: Wydawnictwo „Kodeks”. 
Zarzycki, Zdzisław. 2014. „Zasada niezależności i autonomii Kościoła i państwa czym naprawdę jest?”. W: Konkordat. Ocena z perspektywy 15 lat obowiazywania, red. Piotr Kroczek, 69-117. Kraków: Uniwersytet Papieski Jana Pawła II. Zedler, Feliks. 2011. „Glosa [do postanowienia Sądu Najwyższego z 5.11.2009 r., I CSK 16/09]". Orzecznictwo Sądów Polskich 7: 555-559.

ACTING IN LITIGATION BEFORE AN ECCLESIASTICAL COURT AS A CIRCUMSTANCE EXCLUDING THE PARTIES' LIABILITY FOR THE INFRINGEMENT OF PERSONALITY RIGHTS. COMMENTARY TO THE JUDGMENT OF THE COURT OF APPEALS IN BIAŁYSTOK OF 12 JANUARY 2017, I ACA 676/16

\section{Abstract}

This commentary discusses the judgment entered by the Court of Appeals in Białystok, Poland, wherein the court held that the circumstance of acting in litigation before an ecclesiastical court excluded the parties' liability for the infringement of personality rights. In the author's opinion, the decision merits approval both as to the view concerning the admissibility of the judicial path before a state court in matters of the protection of personality rights violated before an ecclesiastical court and as to the claim that the protection of personality rights is not available in circumstances excluding the unlawfulness of such a violation. Acting before an ecclesiastical court, which operates with the approval of state legislation, fits within the group of cases in which one is acting within the boundaries of the legal order. The legal qualification of activities arising from a party's procedural rights, whether acting before a state court or an ecclesiastical court, requires verifying whether such activities are based on the existing legal right of a subject to act, which means acting within the competence set out by the legal order, citing true facts (or justifiably regarded as true) in a moderate manner and to the extent necessary for the enforcement of the party's right.

Key words: personality rights; canon law; civil law; ecclesiastical court 